\title{
Synthesis of 4-azo-butenolides
}

\section{Ana Paula da Rocha Pissurno \& Rosangela da Silva de Laurentiz}

To cite this article: Ana Paula da Rocha Pissurno \& Rosangela da Silva de Laurentiz (2017) Synthesis of 4-azo-butenolides, Synthetic Communications, 47:20, 1874-1878, DOI: 10.1080/00397911.2017.1354380

To link to this article: https://doi.org/10.1080/00397911.2017.1354380

View supplementary material $\asymp$

Accepted author version posted online: 20 Jul 2017. Published online: 11 Sep 2017.

ए

Submit your article to this journal ๘

凹 Article views: 75

View Crossmark data 


\title{
Synthesis of 4-azo-butenolides
}

\author{
Ana Paula da Rocha Pissurno and Rosangela da Silva de Laurentiz \\ Department of Physics and Chemistry, São Paulo State University (UNESP), Ilha Solteira, São Paulo, Brazil
}

\begin{abstract}
An efficient, catalyst-free, microwave-assisted approach has been developed for the synthesis of 4-azo-butyenolides derivatives by condensing tetronic acid with various anilines. This approach exhibited good functional group compatibility and produced the desired products in good to excellent yields in just $30-40 \mathrm{~min}$. This approach can be seen as a better alternative to protocols with long reaction times used for the synthesis of these compounds, which are synthons for the obtaining of quinolines.
\end{abstract}

GRAPHICAL ABSTRACT<smiles>O=C1COC(=O)C1</smiles><smiles>[R]c1cccc(N)c1</smiles><smiles>[R]c1ccc(NC2=CC(=O)OC2)cc1</smiles>

$\mathrm{R}=$ alkyl, $\mathrm{OCH}_{3}, \mathrm{OCH}_{2} \mathrm{O}$, Halogen

\section{ARTICLE HISTORY}

Received 2 May 2017

\section{KEYWORDS}

Microwave irradiation; quinolines synthons; short reaction time; substrate scope

\section{Introduction}

Heterocyclic natural or synthetic compounds are an important class of molecules for the development of new drugs. ${ }^{[1-3]}$ Several of these compounds containing the quinoline nucleus display innumerous biological properties and are used as drugs against malaria, cardiovascular diseases, allergies, and vasodilators. ${ }^{[4-15]}$ The search for new drugs more potent and with less side effects requires chemical strategies of synthesis that facilitate the obtaining of intermediates for the construction of heterocycles in a quick way and in smaller reaction times, speeding up the process of the synthesis until the biological evaluation. ${ }^{[16]}$

4-Azo-butenolides are synthons for the synthesis of quinolines, dihydroquinolines, lactones, and a large amount of derivatives of great pharmacological interest. ${ }^{[17-20]}$ Despite the importance of these compounds, the syntheses described in the literature use reaction conditions that involve long reaction times and expensive purification processes. ${ }^{[20]}$ These conditions make it difficult to obtain these intermediates for the construction of more complex molecules in quantity and structural variety for biological evaluation. In this work, a new method for the synthesis of 4-azo-butenolide derivatives from reaction between tetronic acid (1) and anilines promoted by microwave is described.

CONTACT Rosangela da Silva de Laurentiz rosangela@dfq.feis.unesp.br @ Department of Physics and Chemistry, São Paulo State University (UNESP), Ilha Solteira 15385 000, São Paulo, Brazil. (-) Supplemental data (full experimental detail, ${ }^{1} \mathrm{H}$ and ${ }^{13} \mathrm{C}$ NMR spectra) can be accessed on the publisher's website. 


\section{Results and discussion}

First, the reaction between equimolar quantity of tetronic acid (1) and 4-bromoaniline (2a) was used as a model for the evaluation of better solvent and temperature for the synthesis (Scheme 1). Dioxane, water, ethanol, acetonitrile, and trifluoroacetic acid (Table 1) were evaluated as a solvent at room temperature and under microwave heating. Results are summarized in Table 1. The product $\mathbf{3 a}$ was purified and its structure was confirmed by ${ }^{1} \mathrm{H}$ NMR and ${ }^{13} \mathrm{C}$ NMR.

Table 1 shows that in the reaction with dioxane has obtained good yield at room temperature (entries 1, Table 1), but with a reaction time of $144 \mathrm{~h}$. Under microwave heating at $200 \mathrm{~W}$, the reaction time decreases, however, the yield also decreases with the formation of by-products as seen by thin-layer chromatography (TLC) (entry 2, Table 1). Microwave heating of dioxane occurs due to the polarity of the starting materials. Water, ethanol, and trifluoracetic acid at room temperature furnished the product $3 \mathbf{a}$ in yield varying between 60 at $70 \%$ with reaction time of $72 \mathrm{~h}$. Under microwave irradiation, these solvents provided the product $\mathbf{3 a}$ in shorter reaction times in yields similar to those obtained at room temperature but with by-product formation. Acetonitrile at room temperature furnished the product $\mathbf{3 a}$ in better yield in the time of $48 \mathrm{~h}$ and $98 \%$ of yield after $30 \mathrm{~min}$ under microwave heating. In protic solvents, used part of the aniline is ionized, while in acetonitrile no ionization and nucleophilic character of nitrogen are maintained. In dioxane also,

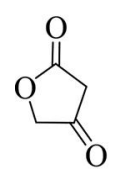

1<smiles>[R]c1ccc(N)cc1</smiles>

2a-j

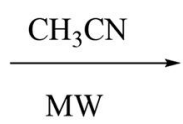

Scheme 1. Reaction between tetronic acid (1) and benzaldehyde derivatives (2a-j) promoted by microwave.

Table 1. Results obtained to the reaction between tetronic acid (1) and Br-aniline (2a) in different solvents.

\begin{tabular}{cllcc}
\hline Entry & Solvent & Temperature $^{b}$ & Time (h) & Yield $^{a}(\%)$ \\
\hline 1 & DX & r.t. & 144 & 86 \\
2 & & MW & 2 & 68 \\
3 & $\mathrm{H}_{2} \mathrm{O}$ & r.t. & 72 & 60 \\
4 & MW & 0.5 & 65 \\
5 & EtOH & r.t. & 72 & 68 \\
6 & & MW & 0.6 & 60 \\
7 & TFA & r.t. & 72 & 70 \\
8 & & MW & 0.6 & 60 \\
9 & $\mathrm{CH}_{3} \mathrm{CN}$ & r.t. & 48 & 75 \\
10 & & MW & 0.5 & 98 \\
\hline
\end{tabular}

${ }_{\text {Isolated product. }}$

${ }^{b} \mathrm{MW}$, microwave reflux temperature of the solvent, $200 \mathrm{~W}$, open vessel.

TFA, trifluoroacetic acid. 
Table 2. Results obtained by reaction between tetronic acid (1) and anilines derivatives (2a-j) promoted by MW.

\begin{tabular}{cccc}
\hline Entry & Aniline & Product & Yield, $(\%)$ \\
\hline 1 & $4-\mathrm{Br}^{*}(2 \mathrm{a})$ & $3 \mathrm{a}$ & 98 \\
2 & $3,4\left(\mathrm{OC}_{2} \mathrm{H}_{4} \mathrm{O}\right)(2 \mathrm{~b})$ & $3 \mathrm{~b}$ & 97 \\
3 & $4-\left(\mathrm{OCH}_{3}\right)(2 \mathrm{c})$ & $3 \mathrm{c}$ & 90 \\
4 & $3-\left(\mathrm{OCH}_{3}\right)(2 \mathrm{~d})$ & $3 \mathrm{~d}$ & 74 \\
5 & $4-\mathrm{C}(2 \mathrm{e})$ & $3 \mathrm{e}$ & 84 \\
6 & $4-\mathrm{CH}^{a}\left(\mathrm{CH}_{3}\right)_{2}(2 \mathrm{f})$ & $3 \mathrm{f}$ & 84 \\
7 & $3,4\left(\mathrm{CCH}_{2} \mathrm{O}\right)(2 \mathrm{~g})$ & $3 \mathrm{~g}$ & 96 \\
8 & $3,4-\left(\mathrm{OCH}_{3}\right)_{2}(2 \mathrm{~h})$ & $3 \mathrm{~h}$ & 93 \\
9 & $3,4-5-\left(\mathrm{CC}_{3}\right)_{3}(2 \mathrm{i})$ & $3 \mathrm{i}$ & 89 \\
10 & $4-\mathrm{CF}_{3}(2 \mathrm{j})$ & $3 \mathrm{j}$ & 88 \\
\hline
\end{tabular}

${ }^{a}$ Isolated yields.

${ }^{b} \mathrm{MW}$, microwave reflux, $200 \mathrm{~W}$, open vessel.

there is no ionization, however, the starting materials are insoluble, therefore, the reaction time is longer. ${ }^{[21]}$

Based on these results, it was established a time of $30-40$ min using acetonitrile as a solvent under microwave heating for the other reactions performed.

After optimization of the reaction conditions, other anilines $(\mathbf{2} \mathbf{b}-\mathbf{j})$ were examined for the synthesis of 4 -azo-butenolides derivatives (3b-j) (Table 2).

The results in Table 2 show that by the use of $\mathrm{CH}_{3} \mathrm{CN} / \mathrm{MW}$ in a reaction time of 30-40 $\mathrm{min}$, it was possible to obtain 4 -azo-butenolide derivatives (3b-j) with high yields (84-91\%). Large yield differences were observed for aniline $\mathbf{2 d}$ which furnished the product $3 \mathbf{d}$ in yield of $74 \%$. The inductively electron-withdrawing methoxy group in the position 3 of the aniline $\mathbf{2 d}$ removes electron density from nitrogen, making it less nucleophilic. $^{\text {[22] }}$

The nucleophilic attack of the nitrogen in the carbonyl of the tetronic acid (1) furnishes the intermediate I (Scheme 2). The MW heating causes an increase in molecular kinetic energy turning faster the reaction ${ }^{[23-26]}$ and the acetonitrile (Lewis base) promotes the remoting of proton $\alpha$-carbonyl and subsequent loss of $\mathrm{H}_{2} \mathrm{O}$ with formation of the product 3 .

In the literature methodologies describing the synthesis of 4-azo-butenolides derivatives, ${ }^{[27-31]}$ however, most of them use anhydrous and toxic solvents such as benzene, low yields, long reaction times, and chromatographic purification methods. Our methodology has the advantage not only of the higher yield but also of the shortest reaction time and the higher purity of the products that do not require chromatographic purification.

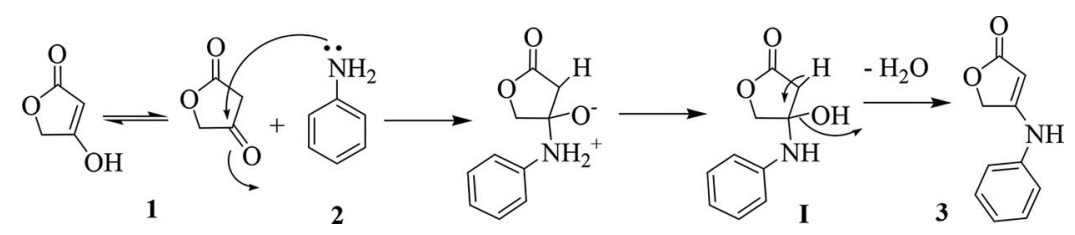

Scheme 2. Mechanistic proposal for reaction between tetronic acid and aniline. 


\section{Experimental}

\section{General procedure for the synthesis of 4-azo-butenolides $3 a$}<smiles>[R]c1ccc(N)cc1</smiles><smiles>CN=CC(C)C</smiles><smiles>[R]c1ccc(NC2=CC(=O)OC2)cc1</smiles>

$\mathrm{R}=$ alkyl, $\mathrm{OCH}_{3}, \mathrm{OCH}_{2} \mathrm{O}$, Halogen

A mixture of tetronic acid $(1.0 \mathrm{mmol})$ and anilines $(1.2 \mathrm{mmol})$ in acetonitrile $(2 \mathrm{~mL})$ was taken in a reaction flask equipped with a small magnetic stirring bar, and the reflux condenser. The mixture was then irradiated in a microwave reactor for $40 \mathrm{~min}$ (reflux temperature of the solvent) at a power of $200 \mathrm{~W}$. Completion of the reaction was monitored by TLC ( $20 \%$ ethyl acetate in hexane). The reaction mixture was then cooled to room temperature and the solvent was removed on rota-evaporator. The precipitated crude product was washed with mixture of hexane-ethyl acetate (8:2) and dried under vacuum to give $3 \mathrm{a}(31.1 \mathrm{mg}, 98 \%)$ as a yellow solid; mp $239-241^{\circ} \mathrm{C}$.

It was obtained as brown solid having mp $247-249^{\circ} \mathrm{C}$ in $98 \%$ yield. ${ }^{1} \mathrm{H}$ NMR $(400 \mathrm{MHz}$, DMSO-d6): $\delta(\mathrm{ppm}) 9.83(\mathrm{~s}, 1 \mathrm{H}, \mathrm{NH}), 7.53(\mathrm{~d}, 2 \mathrm{H}$ arom, $J=8.8 \mathrm{~Hz}), 7.16(\mathrm{~d}, 2 \mathrm{H}$ arom, $J=8.8 \mathrm{~Hz}$ ), 5.36 (s, 1H), $4.87(\mathrm{~s}, 2 \mathrm{H}) .{ }^{13} \mathrm{C}$ NMR (100 MHz, DMSO-d6): $\delta$ (ppm) 174.80, 162.32, 139.52, 132.18, 120.47, 114.58, 84.47, 68.04. HRMS $\left(\mathrm{ESI}^{+}\right): \mathrm{m} / \mathrm{z}[\mathrm{M}+\mathrm{H}]^{+}$calcd for $\mathrm{C}_{10} \mathrm{H}_{9} \mathrm{NBrO}_{2}$ : 253.9816; found: 253.9810 .

\section{Conclusion}

Finally, we can conclude that the use of acetonitrile and MW heating in the reaction between tetronic (1) and aniline derivatives $(\mathbf{2} \mathbf{a}-\mathbf{j})$ produces new 4 -azo-butenolide derivatives with excellent yields, in a very efficient manner. This reaction condition can be applied using anilines with electron-withdrawing substituents as well as electron-donating substituents at different positions on the aromatic ring.

\section{Acknowledgments}

The authors would like to thank Fundação de Amparo à Pesquisa do Estado de São Paulo (FAPESP) (Proc. 2014/07493-5) for their financial support and Coordenacão de Aperfeiçoamento de Pessoal de Nível Superior (CAPES) for scholarship.

\section{References}

[1] Gomtsyan, A. Chem. Heterocycl. Compd. 2012, 48(1), 7-10.

[2] Martins, P.; Jesus, J.; Santos, S.; Raposo, L. R.; Roma-Rodrigues, C.; Baptista, P. V.; Fernandes, A. R. Molecules 2015, 20, 16852-16891.

[3] Taylor, A. P.; Robinson, R. P.; Fobian, W. M.; Blakemore, D. C.; Jones, L. H.; Fadeyi, O. Org. Biomol. Chem. 2016, 14, 6611-6637.

[4] Bawa, S.; Kumar, S.; Drabu, S.; Kumar, R. J. Pharm. Bioallied Sci. 2010, 2(2), 64-71. 
[5] Ladania, G. G.; Patel, M. P. New J. Chem. 2015, 39, 9848-9857.

[6] Kumar, S.; Bawa, S.; Gupta, H. Mini Rev. Med. Chem. 2009, 9(14), 1648-1654.

[7] Marella, A.; Tanwar, O. P.; Saha, R.; Ali, M. R.; Srivastava, S.; Akhter, M.; Shaquiquzzaman, M.; Alam, M. M. Saudi Pharm. J. 2013, 21(1), 1-12.

[8] Akhter, M.; Saha, R.; Tanwar, O.; Alam, M.; Zaman, M. S. Med. Chem. Res. 2015, 24(2), 879-890.

[9] Li, Y. R. Cardiovascular Diseases: From Molecular Pharmacology to Evidence-Based Therapeutics; John Wiley \& Sons: New Jersey, 2015.

[10] Gilmore, C. D.; Alan K. M.; Stoltz, B. M. J. Am. Chem. Soc. 2008, 130, 1558-1559.

[11] Farrow, S. C.; Facchin, P. J. FEBS Lett. 2015, 589(19), 2701-2706.

[12] Spinozzi, F.; Russano A. M.; Piattoni, S.; Agea, E.; Bistoni, O.; de Benedictis, D.; de Benedictis, F. M. Clin. Exp. Allergy 2004, 34(12), 1876-1882.

[13] Saggadi, H.; Luart, D.; Thiebault, N.; Polaert, I.; Estel, L.; Len, C. Catal. Commun. 2014, 44, 15-18.

[14] Saggadi, H.; Luart, D.; Thiebault, N.; Polaert, I.; Estel, L.; Len, C. RSC $A d v$. 2014, 4, 21456-21464.

[15] Saggadi, H.; Polaert, I.; Luart, D.; Len, C.; Estel, L. Catal. Today 2015, 255, 66-74.

[16] Nicolaou, K. C.; Hale, C. R.; Nilewski, C.; Ioannidou, H. A. Chem. Soc. Rev. 2012, 41, $5185-5238$.

[17] Naeimi, H.; Rashid, Z.; Zarnani, A. H.; Ghahremanzadeh, R. J. Chem. 2013, Article ID 169695, 9.

[18] Tu, S.; Zhang, Y.; Jia, R.; Jiang, B.; Zhang, J.; Ji, S. Tetrahedron Lett. 2006, 47(37), 6521-6525.

[19] Shi, C.-L.; Chen, H.; Shi, D. J. Heterocycl. Chem. 2012, 49(1), 125-129.

[20] Hitotsuyanagi, Y.; Kobayashi, M.; Fukuyo, M.; Takeya, K.; Itokawa, H. Tetrahedron Lett. 1997, 38(48), 8295-8296.

[21] Muney, W. S.; Coetzee, J. F. J. Phys. Chem. 1962, 66(1), 89-96.

[22] Carey, A. F. Organic Chemistry Chapter 12: Reactions of Arenes. Electrophilic Aromatic Substitution, 4th ed.; McGraw-Hill College: Boston, 2000.

[23] Larhed, M.; Hallberg, A. Drug Discov. Today 2001, 6, 406-416.

[24] Santagada, V.; Frecentese, F.; Perissutti, E.; Fiorino, F.; Severino, B. Mini Rev. Med. Chem. 2009, 9, 340-358.

[25] Sekhon, B. S. Int. J. Pharm. Tech. Res. 2010, 2(1), 827-833.

[26] De La Hoz, A.; Díaz-Ortiz, A.; Prieto, P. Alternative Energy Sources for Green Chemistry; Royal Society of Chemistry: Cambridge, England, 2016; chap 1, pp 1-33.

[27] Momose, T.; Toyooka, N.; Nishi, T.; Takeuchj, Y. Heterocycles 1988, 27(8), 1907.

[28] Boosen, K. J. Helv. Chim. Acta 1977, 60, 1256-1261.

[29] Bohme, H.; Weisel, K. H. Arch. Pharm. 1977, 310, 26-29.

[30] Greenhill, J. V.; Ramli, M.; Tomassini, T. J. Chem. Soc. Perkin Trans. I 1975, 588-591.

[31] Semenova, M. N.; Kiselyov, A. S.; Tsyganov, D. V.; Konyushkin, L. D.; Firgang, S. I.; Semenov, R. V.; Malyshev, O. R.; Raihstat, M. M.; Fuchs, F.; Stielow, A.; Lantow, M. J. Med. Chem. 2011, 54(20), 7138-7149. 